\title{
SELAYANG PANDANG SEJARAH PENYUSUNAN KOMPILASI HUKUM ISLAM DI INDONESIA
}

\author{
Hikmatullah \\ Program Studi Hukum Keluarga UIN Sultan Maulana Hasanuddin Banten \\ Email: hikmatullah.arken@gmail.com
}

\begin{abstract}
Abstrak
Terbentuknya hukum Islam (hukum keluarga) yang tertulis, sebenarnya sudah lama menjadi kebutuhan dan keinginan masyarakat muslim. Sejak terbentuknya Peradilan Agama yang mempunyai kewenangan untuk menyelesaikan masalah-masalah hukum keluarga, rasanya sangat diperlukan adanya hukum kekeluargaan Islam tertulis. Maka munculah gagasan penyusunan Kompilasi Hukum Islam sebagai upaya dalam rangka mencari pola fiqh yang bersifat khas Indonesia atau fiqh yang bersifat kontekstual. Sejatinyaproses ini telah berlangsung lama sejalan dengan perkembangan hukum Islam di Indonesia atau paling tidak sejalan dengan kemunculan ide-ide pembaharuan dalam pemikiran hukum Islam Indonesia. Kemunculan KHI di Indonesia dapat dicatat sebagai sebuah prestasi besar yang dicapai umat Islam. Setidaknya dengan adanya KHI itu, maka saat ini di Indonesia tidak akan ditemukan lagi pluralisme Keputusan Peradilan agama, karena kitab yang dijadikan rujukan hakim Peradilan Agama adalah sama. Selain itu fikih yang selama ini tidak positif, telah ditransformasikan menjadi hukum positif yang berlaku dan mengikat seluruh umat Islam Indinesia. Lebih penting dari itu, KHI diharapkan akan lebih mudah diterima oleh masyarakat Islam Indonesia karena ia digali dari tradisi-tradisi bangsa indonesia. Jadi tidak akan muncul hambatan Psikologis di kalangan umat Islam yang ingin melaksanakan Hukum Islam.
\end{abstract}

Kata Kunci: Sejarah Hukum, Kompilasi Hukum Islam

\section{Latar Belakang dan Proses Penyusunan Kompilasi Hukum Islam (KHI)}

Indonesia adalah negara yang mayoritas penduduknya muslim, dan konon merupakan yang terbesar di dunia. ${ }^{1}$ Hukum Islam sebagai tatanan hukum yang dipedomani dan ditaati oleh mayoritas penduduk dan masyarakat Indonesia adalah hukum yang telah hidup dalam masyarakat, dan merupakan sebagian dari ajaran dan keyakinan Islam yang eksis dalam kehidupan hukum nasional, serta merupakan bahan dan pembinaan dan pengembangannya. $^{2}$

Umat Islam Indonesia yang merupakan penduduknya mayoritas di negeri

${ }^{1}$ M. Hafidz Al-Ashqia, Kaya Wajib Bagi Orang Islam, (Yogyakarta: Khazanah Sulaiman, 2011), h.4. ini, salah satu upaya dalam rangka pengamalan syari'at Islam, adalah menjadikan hukum Islam itu sebagai hukum positif di Indonesia. Keberhasilan umat Islam untuk menjadikan hukum Islam sebagai hukum positif, antara lain telah nampak pada perumusan Pancasila sebagai landasan filosofis bangsa, sebagaimana tertuang dalam Piagam Jakarta, yang menegaskan bahwa negara Republik Indonesia berdasarkan kepada Ketuhanan dengan kewajiban menjalankan syari'at Islam bagi pemeluk -pemeluknya. Landasan filosofis tersebut diikuti oleh dan merupakan rangkaian kesatuan dengan Piagam Jakarta, sebagaimana ditegaskan dalam Dekrit Presiden tanggal 5 Juli 1959.

${ }^{2}$ Mardani, Hukum Islam, (Yogyakarta: Pustaka Belajar, 2010), h.171 
Obyek pembahasan hukum Islam yang begitu luas dan dalam itu sejalan dengan rumusan ta'rif hukum Islam yang antara lain dikatakan, "berhubungan dengan perbuatan mukallaf'. perbuatan mukallaf tiada habishabisnya. Semakin bertambah maju umat manusia semakin bertambah maju pula tingkat intensitas gerak dan aktifitasnya. Semuanya itu harus terekam oleh hukum Islam (harus ada hukumnya). Jadi, kedalaman dan keluasan hukum Islam itu harus sanggup menampung sekian banyak gerak langkah kehidupan manusia yang tiada batasnya itu. ${ }^{3}$

Setelah Indonesia merdeka, ditetapkan 13 kitab fikih sebagai referensi hukum materiil di pengadilan agama melalui Surat Edaran Kepala Biro Pengadilan Agama RI. No. $\mathrm{B} / 1 / 735$ tanggal 18 februari 1985. Hal ini dilakukan karena hukum Islam yang berlaku di tengah-tengah masyarakat ternyata tidak tertulis dan berserakan di berbagai kitab fikih yang berbeda-beda.

Akan tetapi penetapan kitab-kitab fikih tersebut juga tidak berhasil menjamin kepastian dan kesatuan hukum di pengadilan agama. Muncul persoalam krusial yang berkenaan dengan tidak adanya keseragaman para hakim dalam menetapkan keputusan hukum terhadap persoalan-persoalan yang mereka hadapi. Berbagai hal dan situasi hukum Islam itulah yang mendorong dilakukannya kompilasi terhadap hukum Islam di Indonesia untuk menjamin kepastian dan kesatuan penerapan hukum Islam di Indonesia.

Hal ini disebabkan tidak tersedianya kitab materi hukum Islam yang sama. Secara material memang telah ditetapkan 13 kitab yang dijadikan rujukan dalam memutuskan perkara yang kesemuanya bermazhab Syafi'i. Akan tetapi tetap saja menimbulkan persoalan

\footnotetext{
${ }^{3}$ Badri Khaeruman, Hukum Islam, (Bandung: Pustaka Setia, 2010), h.24.

4

aafandia.wordpress.com/2009/05/20/instruksipresiden-ri-nomor-1-tahun-1991-tentang-kompilasihukum-islam/
}

yaitu tidak adanya keseragaman keputusan hakim.

Bustanul Arifin adalah seorang tokoh yang tampil dengan gagasan perlunya membuat Kompilasi Hukum Indonesia. Gagasan-gagasan ini didasari pada pertimbangan-pertimbangan berikut:

1. Untuk berlakunya hukum Islam di Indonesia, harus ada antara lain hukum yang jelas dan dapat dilaksanakan oleh aparat penegak hukum maupun oleh masyarakat.

2. Persepsi yang tidak seragam tentang syari'ah menyebabkan hal-hal: 1. Ketidakseragaman dalam menentukan apa-apa yang disebut hukum Islam itu (maa anzalallahu), 2. Tidak mendapat kejelasan bagaimana menjalankan syari'at itu (Tanfiziyah) dan 3. Akibat kepanjangannya adalah tidak mampu menggunakan jalan-jalan dan alat-alat yang tersedia dalam Undang-Undang Dasar 1945 dan perundangan lainya.

3. Di dalam sejarah Islam, pernah ada tiga Negara dimana hukum Islam diberlakukan (1). Sebagai perundang-undangan yang terkenal dalam fatwa Alamfiri, (2). Di kerajaan Turki Ustmani yang terkenal dengan nama Majallah al-Ahkam Al-Adliyah dan (3). Hukum Islam pada tahun 1983 dikodifikasikan di Subang. ${ }^{4}$

UUD 1945 secara keseluruhan, baik naskah maupun isinya tidak bertentangan dan terdapat kesesuain dengan prinsip-prinsip dalam hukum Islam. Keberhasilan berikutnya dalam upaya menjadikan hukum Islam sebagai hukum positif di Indonesia terlihat dengan terbentuknya lembaga dan instansi keagamaan, serta lahirnya perundang-undangan, antara lain seperti UU No.1 Tahun 1974 tentang Perkawinan, Kompilasi Hukum Islam (KHI) di Indonesia Tahun 1991. ${ }^{5}$

Keberhasilan umat Islam Indonesia merupakan materi hukum Islam secara tertulis

5 Yusuf Somawinata, "Al-Maslahah AlMursalah dan Implikasi Terhadap Dinamisasi Hukum Islam Di Indonesia," dalam Al-Ahkam: Jurnal Hukum, Sosial dan Keagamaan, Vol. 4, No. 2 (Juli-Desember, 2010), h.87. 
dalam peraturan perundang-undangan tersebut, merupakan wujud konkret dalam rangka memberlakukan hukum Islam bagi umat Islam Indonesia, yang sudah lama dicitacitakan, sehingga terjamin adanya kesatuan dan kepastian hukum. Sebab untuk dapat berlakunya hukum Islam di Indonesia, harus ada antara lain hukum yang jelas dan dapat dilaksanakan baik oleh aparat penegak hukum maupun oleh masyarakat. ${ }^{6}$

Semangat untuk memberlakukan syari'at Islam, khususnya dalam bidang perdata, bukan hanya wujud dalam tataran masyarakat sebagai pelaksana hukum saja, melainkan juga didukung oleh lembagalembaga pemerintah sebagai aparat penegak hukum. Hal itu dibuktikan dengan adanya Surat Edaran Departemen Agama cq. Biro Peradilan Agama Nomor B/1/735 Tanggal 18 pebruari 1958 yang ditujukan kepada Pengadilan Agama dan Pengadilan Tinggi Agama di seluruh Indonesia agar dalam memeriksa, mengadili, dan memutuskan perkara, berpedoman kepada 13 kitab fiqh yang sebagian besar kitab fiqh tersebut berlaku di kalangan madzhab Syafi' i. ${ }^{7}$

Salah satu tujuan yang ingin dijelaskan Undang-undang Peradilan Agama, adalah mempertegas kedudukan dan kekuasaan lingkungan Peradilan Agama sebagai salah satu bagian dari pelaksana "kekuasaan kehakiman" atau disebut juga dengan "judicial power" dalam negara Republik Indonesia. ${ }^{8}$

Begitu banyak pendapat dalam suatu madzhab sehingga melahirkan putusan yang tidak seragam dalam praktek hukum Islam yang berlaku di Pengadilan. Putusan yang sangat bervariasi mengancam kepastian hukum bagi pencari keadilan di mana kasus yang sama memungkinkan adanya putusan yang lebih dari satu. Pendapat yang berbedabeda dalam fiqh Islam sudah barang tentu

\footnotetext{
${ }^{6}$ Ibid

7 Hani Solihah, "Sejarah Hukum Keluarga Islam di Indonesia," dalam Syakhsia: Jurnal Hukum Perdata Islam, Vol. 2, No. 2 (Agustus-Desember), h.67.
}

membawa kepada putusan yang berbeda-beda pula di lembaga Peradilan, dab selanjutnya akan memperjauh kesatuan persepsi dalam penerapan hukum.

Implementasi hukum Islam bagi umat Islam kadang-kadang menimbulkan pemahaman yang berbeda. Hukum Islam yang diterapkan di Pengadilan Agama cenderung simpang siur disebabkan oleh perbedaan pendapat para ulama dalam hampir setiap persoalan. ${ }^{9}$

Lahirnya KHI tidak dapat dipisahkan dari latar belakang dan perkembangan (pemikiran) hukum Islam di Indonesia. Di satu sisi, pembentukan KHI terkait erat dengan usaha-usaha untuk keluar dari situasi dan kondisi internal hukum Islam yang masih diliputi suasana kebekuan intelektual yang akut. Di sisi lain, KHI mencerminkan perkembangan hukum Islam dalam konteks hukum nasional, melepaskan diri dari pengaruh teori receptie, khususnya dalam rangkaian usaha pengembangan Pengadilan Agama.

Hukum Islam di Indonesia memang sejak lama telah berjalan di tengah-tengah masyarakat. Namun harus dicatat bahwa hukum Islam tersebut tidak lain merupakan hukum fiqh hasil interpretasi ulama-ulama abad ke dua hijriyah dan abad-abad sesudahnya. Pelaksanaan hukum Islam sangat diwarnai suasana taqlid serta sikap fanatisme mazhab yang cukup kental. Ini makin diperparah dengan anggapan bahwa fiqh identik dengan Syari'ah atau hukum Islam yang merupakan wahyu aturan Tuhan, sehingga tidak dapat berubah. Umat Islam akhirnya terjebak ke dalam pemahaman yang tumpang tindih antara yang sakral dengan yang profan.

\footnotetext{
8 Yahya Harahap, "Kedudukan Kewenangan dan Acara Peradilan Agama, (Jakarta: Pustaka Kartini, 1993), cet.ke-2, h.25.

${ }^{9}$ Dirjen Binbaga Islam, Sejarah Penyusunan Kompilasi hukum Islam di Indoesia, (Jakarta: Departemen Agama RI, 1991), h.139.
} 
Situasi tersebut berimplikasi negatif terhadap pelaksanaan hukum Islam di lingkungan Peradilan Agama. Pengidentifikasian fiqh dengan Syari'ah atau hukum Islam sepertiitu telah membawa akibat kekeliruan dalam penerapan hukum Islam yang sangat "keterlaluan". Dalam menghadapi penyelesaian kasus-kasus perkara di lingkungan peradilan agama, para hakim menoleh kepada kitab-kitab fiqh sebagai rujukan utama. Jadi, putusan pengadilan bukan didasarkan kepada hukum, melainkan doktrin serta pendapat-pendapat mazhab yang telah terdeskripsi di dalam kitab-kitab fiqh.

Akibat dari cara kerja yang demikian, maka lahirlah berbagai produk putusan Pengadilan Agama yang berbeda-beda meskipun menyangkut satu perkara hukum yang sama. Hal ini menjadi semakin rumit dengan adanya beberapa mazhab dalam fiqh itu sendiri, sehingga terjadi pertarungan antar mazhab dalam penerapan hukum Islam di Pengadilan Agama. ${ }^{10}$

Disamping itu kadang-kadang masih adanya kerancuan dalam memahami fiqh, yang dipandang sebagai hukum yang harus diberlakukan, bukan sebagai pendapat (doktrin, fatwa) ulama yang dijadikan bahan pertimbangan dalam menetapkan hukum. Pada saat itulah dirasakan adanya keseragaman pemahaman dan kejelasan bagi kesatuan hukum Islam yang akan dan harus dijadikan pegangan oleh para hakim di lingkungan Peradilan Agama. Keinginan untuk menyeragamkan hukum Islam itu, menimbulkan gagasan sampai terwujudnya Kompilasi Hukum Islam (KHI) di Indonesia. Oleh karena untuk dapat berlakunya hukum Islam di Indonesia, harus ada antara lain hukum yang jelas dan dapat dilaksanakan baik oleh para aparat penegak hukum maupun oleh masyarakat. ${ }^{11}$

${ }^{10}$ Zainuddin Ali, Hukum Islam : Pengantar Ilmu Hukum Islam di Indonesia (Jakarta: Sinar Grafika, 2006), h. 98

${ }^{11}$ Suparman Usman, Hukum Islam, (Jakarta: Gaya Media Pratama, 2011), cet.ke-2, h.145.
Prospek hukum Islam dalam sistem hukum nasional akan cukup menggembirakan sepanjang pihak- pihak yang terkait dalam pengembangan hukum Islam mampu untuk mengoptimalkan kekuatan dan peluang yang dimiliki hukum Islam, serta mampu mengeliminir kekurangan dan hambatan yang ada dan mencarikan solusinya. ${ }^{12}$

Dengan dikeluarkanya UU No. 14 tahun 1970 tentang Ketentuan Pokok Kekuasaan Kehakiman semakin mempertegas keberadaan peradilan agama. Pasalnya dalam pasal 10 undang-undang tersebut disebutkan; ada empat lingkungan peradilan di Indonesia, yaitu peradilan umum, perdilan agama, peradialan militer, dan peradilan tata usaha negara. Klausula pada undang undang tesebut scara tegas memposisikan peradilan agama sejajar dengan peradilan lain yang sebelumnya hanya dibawah Kementrin Agama. Oleh karena itu, secara tidak langsung kekuatan peradilan agama sama dengan pengadilanpengadilan lainnya yang ada di wilayah yurisdiksi Indonesia.

Ide penyusunan kompilasi hukum Islam timbul setelah beberapa tahun Mahkamah Agung membina bidang tehnik yustisial Peradilan Agama.Tugas pembinaan ini juga didasari oleh UUD No.14 tahun 1970 tentang kekuasaan pokok kehakiman. Pasal 2 ayat 1 menyatakan" : penyelenggaraan kekuasaan kehakiman tercantum pada pasal 1 diserahkan kepada badan-badan peradilan dan ditetapkan dengan undang-undang dengan tugas pokok untuk menerima, memeriksa dan mengadili serta menyelesaikan setiap perkara yang di ajukan kepadanya". ${ }^{13}$

Selama membina Pengadilan Agama Mahkamah Agung memandang adanya beberapa kelemahan, seperti hukum Islam yang diterapkan dilingkungan Peradilan Agama yang cenderung simpang siur karena

\footnotetext{
12 Zakaria Syafe'i, Sanksi Hukum Riddah dan Implementasinya di Indonesia, (Jakarta: Media Pustaka, 2012), h.13.

${ }^{13}$ Basiq Jalil, Pengadilan Agama di Indonesia, ( Jakarta : Kencana Prenada Media Group, 2006 ), cet. ke-1, h.109
} 
adanya perbedaan pendapat ulama dalam menetapkan suatu hukum dilingkungan peradilan didasari oleh perbedaan sumber rujukan yang dijadikan hakim untuk memutuskan perkara-perkara. Sebagai realisasi ketentuan di atas, pada tahun 1974 dikeluarkannya UU No.1 tahun 1974 tentang perkawinan. Undang-undang ini merupakan kodifikasi dan unifikasi hukum perkawinan di Indonesia, berlaku bagi seluruh warga negara. ${ }^{14}$

Sebelum lahirnya undang undang perkawinan pemerintah mencoba menindaklanjuti pesan undang undang No.14 tahun 1970, proses ini membutuhkan waktu yang cukup lama, hingga akhirnya rancangan undang-undang Peradilan Agama dapat di ajukan dan disahkan dan di undangkan tanggal 29 Desember tahun 1989 melalui lembaran Negara Republik Indonesia Nomor 49. Upaya ini bukanlah semata mata untuk memenuhi ketentuan undang-undang No 14 tahun 1970 tetapi untuk memenuhi dan menghadirkan suatu Peradilan Agama seperti yang dikehendaki pasal 63 ayat 1 undang-undang perkawinan. ${ }^{15}$

Pada tahun 1977 Mahkamah Agung mengeluarkan peraturan yang semakin memperkuat bagi kedudukan Pengadilan Agama, yaitu dengan diberikannya hak bagi Pengadilan Agama untuk mengajukan kasasi ke Mahkamah Agung. Peraturan tersebut semakin memperkokoh keberadaan Peradilan Agama. ${ }^{16}$

Seiring dengan perjalanan waktu, kitab-kitab fiqh yang dipakai di Pengadilan Agama juga mulai tersaring dengan sendirinya sehingga tidak lagi tidak terbatas seperti sebelumnya. Penyaringan tersebut barangkali terjadi secara alami mengingat keterbatasan pengetahuan hakim yang bertugas di Pengadilan seperti di pondok pesantren dan madrasah. Akhirnya Surat Edaran Biro

\footnotetext{
${ }^{14}$ Ahmad Rofiq, op.cit, h.37

${ }^{15}$ Ibid, h. 40

${ }^{16}$ Abdurrahman, Kompilasi Hukum Islam di
} Indonesia........ h. 76-77
Peradilan Agama No. B/I/735 Tanggal 18 Februari 1958 sebagai pelaksana PP No. 45 Tahun 1957 tentang Pembentukan Pengadilan Agama/Mahkamah Syar'iyyah di luar Jawa dan Madura menganjurkan hakim agama menggunakan sebanyak 13 kitab fiqh sebagai pedoman. berikut:

Kitab-kitab tersebut adalah sebagai

a. Al-Bajuri;

b. Fathul Mu'in;

c. Asy-Syarkawi 'ala at-Tahrir;

d. Al-Qalyubi/al-Mahalli;

e. Fathu al-Wahhab wa Syarhuh;

f. At-Tuhfah;

g. Targhib al-Musytaq;

h. Al-Qawanin asy-Syar'iyyah li Sayyid bin Yahya;

i. Al-Qawanin asy-Syar'iyyah li Sayyid Shadaqoh Dachlan;

j. Asy-Syamsuri fi al-Faraid;

k. Bughyah al-Mustarsyidin;

1. Al-Fiqh 'ala al-Madzahib alArba'ah;

m. Al-Mughni al-Muhtaj.

Dengan merujuk 13 buah kitab ini yang dianjurkan maka langkah ke arah kepastian hukum semakin nyata. Meskipun secara materi kitab-kitab tersebut terkenal keabsahannya, namun hal tersebut tidak memecahkan masalah yang ada. Justru menambah kesemrawutan rujukan hukum bagi Peradilan Agama. ${ }^{17}$

Perkembangan ini menyebabkan lembaga Peradilan Agama harus meningkatkan kemampuannya agar dapat melayani para pencari keadilan dan memutuskan perkara dengan sebaik-baiknya dan seadil-adilnya, kemampuan seperti itu akan ada apabila terdapat satu hukum yang jelas dalam satu kitab kumpulan garis-garis hukum yang dapat digunakan oleh hakim

${ }^{17}$ Direktorat Pembinaan Badan Peradilan Agama, Inpres RI No.1 Tahun 1991 Kompilasi Hukum Islam di Indonesia, (Jakarta: Depag RI, 2000), h.128. 
Peradilan Agama. Atas pertimbangan inilah, mungkin antara lain melahirkan surat keputusan besar ketua Mahkamah Agung dan Menteri Agama pada tanggal 21 maret 1984 membentuk sebuah panitia yang diberi tugas untuk menyusun kompilasi hukum Islam. Dan hukum Islam apabila tidak dikompilasikan maka berakibat pada tidak seragam dalam menentukan hukum Islam, tidak jelas bagaimana menerapkan syariah, tidak mampu menggunakan jalan alat yang telah tersedia dalam UU 1945 . $^{18}$

\section{Walaupun rujukan di Pengadilan} sudah disederhanakan, tapi mengingat kemampuan hakim agama zaman sekarang yang tidak banyak di antara mereka yang memahami bahasa Arab dan kitab-kitab klasik berbahasa Arab, maka ternyata penyederhanaan itu masih sangat memberatkan bagi kebanyakan hakim. Keadaan rujukan dalam bahasa Arab juga menyulitkan para pengacara dan pihak-pihak yang terlibat dalam perkara untuk memahami dalil-dalil hukum yang digunakan. ${ }^{19}$

Ternyata Kompilasi Hukum Islam (KHI) telah berjalan dengan tidak ada kendala yang berarti, yakni sejak tahun 1991 sampai dengan tahun 2004. Namun pada awal tahun 2005 telah terjadi adanya pihak yang menganggap bahwa Kompilasi Hukum Islam (KHI) tidak dapat merespon semua bangsa Indonesia. $^{20}$

Apa sebenarnya yang menjadi latar belakang penyusunan Kompilasi Hukum Islam (KHI) tidaklah mudah untuk dijawab secara singkat. Bilamana kita memperhatikan konsideran Keputusan Bersama Ketua Mahkamah Agung dan Menteri Agama tanggal 1 Maret 1985 No.07/KMA1985 dan No. 25

${ }^{18}$ Abdul Halim, Politik Hukum Islam di Indonesia Kajian Posisi Hukum Islam Dalam Politik Hukum Pemerintahan Orde Baru dan Era Reformasi, ( Tt : Badan Litbang dan Diklat Departemen Agama RI, 2008 ), cet. ke-1, h.259

19 Sohari, "Gugatan Pengarusutamaan Gender (TPG) dan JIL Terhadap Kompilasi Hukum tahun 1985 tentang Penunjukan Pelaksanaan Proyek Pembangunan Hukum Islam melalui yurisprudensi atau yang lebih dikenal dengan sebagai proyek Kompilasi Hukum Islam (KHI), dikemukakan ada dua pertimbangan mengapa proyek ini diadakan, yaitu:

a. Bahwa sesuai fungsi pengaturan Mahkamah Agung Republik Indonesia terhadap jalannya peradilan di semua lingkungan peradilan di Indonesia, khususnya di lingkungan Peradilan Agama, perlu mengadakan Kompilasi Hukum Islam (KHI) yang selama ini menjadikan hukum positif di Pengadilan Agama;

b. Bahwa guna mencapai maksud tersebut, demi meningkatkan kelancaran pelaksanaan tugas, sinkronisasi dan tertib administrasi dalam proyek pembangunan Hukum Islam melalui yurisprudensi, dipandang perlu membentuk suatu tim proyek yang susunannya terdiri dari para Pejabat Mahkamah Agung dan Departemen Agama Republik Indonesia.

Bila kita perhatikan, konsideran tersebut masih belum memberikan jawaban yang tegas mengenai mengapa kita harus membentuk kompilasi dimaksud. Bilamana kita teliti lebih lanjut ternyata pembentukan Kompilasi Hukum Islam (KHI) ini mempunyai kaitan yang erat sekali dengan kondisi hukum Islam di Indonesia selama ini. ${ }^{21}$

Dari proses penyusunan Kompilasi Hukum Islam (KHI) dari awal sampai akhir dengan segala tahapannya dapat diketahui bahwa yang menjadi sumber rujukan bagi penyusunan Kompilasi Hukum Islam (KHI) itu adalah sebagai berikut:

Islam(KHI)," dalam Syakhsia: Jurnal Hukum Perdata Islam, Vol. 3, No. 1 (Juli-Desember,2011), h.5.

${ }^{20}$ Ibid, h.6.

${ }^{21}$ Abdurrahman, Kompilasi Hukum Islam, (Jakarta: Akademika Pressindo, 2007), h.15. 
a) Hukum perundang-undangan berkenaan dengan perkawinan, yaitu UU No.32 Tahun 1954; UU No.1 Tahun 1974; PP No.9 Tahun 1975 dan PP No.7 Tahun 1989 sebagai sumber rujukan, memang terasa agakjanggal; karena UU No.7 Tahun 1989 itu diundangkan pada tanggal 29 Desember 1989, dengan Lokakarya Ulama sebagai tahap akhir dari kegiatan penyusunan Kompilasi Hukum Islam (KHI) berlaku tanggal 2 sampai tanggal 6 Februari 1988. Namun kenyataannya materi yang terdapat dalam Kompilasi Hukum Islam (KHI) berkenaan dengan Hukum Acara, hampir semuanya sama dengan rumusan yang terdapat pada UU No. 7 Tahun 1989. Mungkin materi yangterdapat dalam Kompilasi Hukum Islam (KHI) tersebut diambil dari Rancangan undang-undang yang memang sudah lama dipersiapkan.

b) Kita-kitab fiqh dari berbagai bermadzhab, meskipun yang terbanyak adalah dari madzhab Syafi'i. Dari daftar kitab fiqh yang ditelaah untuk perumusan Kompilasi Hukum Islam (KHI) itu kelihatannya kitab-kitab tersebut berasal dari madzhab Syafi'i, Hanafi, Maliki, Hambali dan Zhahiri. Memang pernah digunakan kitab fiqh dari madzhab Syi'ah Imamiyah dalam telaah kitab itu, yaitu al-Mabsuth Fi Fiqh al-Imamiyah, karya al-Thusiy, namun dalam daftar kitab yang dibaca tidak ada kelihatan kitab fiqh yang berasal dari madzhab Syi'ah Imamiyah tersebut.

c) Hukum adat yang berlaku di Indonesia sebagaimana yang tampil dalam beberapa yurisprudensi Pengadilan Agama, namun kelihatannya tidak banyak yang langsung diambil Kompilasi Hukum Islam (KHI) dari Hukum Adat. Seandainya ada praktik adat itu terdapat dalam Kompilasi Hukum Islam (KHI) seperti harta bersama dalam perkawinan, namun tidak diambil

${ }^{22}$ Amir Syarifuddin, Hukum Perkawinan Islam di Indonesia antara Fiqh Munakahat dan Undangundang Perkawinan, (Jakarta: Kencana, 2006), cet.ke-3, h. 24 .
Kompilasi Hukum Islam mengambilnya dari Hukum Adat. Mungkin yang dapat dijadikan contoh pengambilan dari adat itu adalah bolehnya mengawini perempuan hamil karena zina, yang kebetulan juga diakui oleh fiqh munakahat. ${ }^{22}$

Kompilasi Hukum Islam (KHI) disusun atas prakasa penguasa negara, dalam hal ini Ketua Mahkamah Agung dan Menteri Agama (melalui Surat Keputusan Bersama) dan mendapat pengakuan ulama dari berbagai unsur. Secara resmi Kompilasi Hukum Islam (KHI) merupakan hasil konsensus (ijma') ulama dari berbagai golongan melalui media lokakarya yang dilakukan secara nasional, yang kemudian mendapat legalisasi dari kekuasaan negara.

Kompilasi Hukum Islam atau yang lebih familiar dengan sebutan KHI merupakan ekspetasi tertinggi yang mampu dicapai hukum Islam saat ini, khususnya di Indonesia. Meski memberikan dampak positif baik dari segi institusi, masyarakat, maupun dinamika pemikiran hukum Islam, keberadaan KHI masih membawa polemik. Tidak hanya proses pemberlakuanya, penamaan kompilasi juga memberikan perdebatan sendiri di kalangan para cendikiawan.

Adanya perdebatan istilah kompilasi dalam term Kompilasi Hukum Islam disebabkan kurang populernya kata tersebut digunakan, baik digunakan dalam pergaulan sehari-hari, praktik, bahkan dalam kajian hukum sekalipun. ${ }^{23}$ Kompilasi diambil dari bahasa Inggris compilation danCompilatie dalam bahasa Belanda yang diambil dari kata compilare yang artinya mengumpulkan bersama-sama, seperti misalnya mengumpulkan peraturan peraturan yang tersebar berserakan dimana-mana. ${ }^{24}$ dalam Kamus Besar Bahasa Indonesia kompilasi adalah kumpulan yang tersusun secara teratur

\footnotetext{
${ }^{23}$ Abdurrahman, Kompilasi Hukum Islam di Indonesia........ hal. 9

${ }^{24}$ 1Ibid, hal. 10
} 
(tentang daftar informasi, karangan dsb). ${ }^{25}$

Berdasarkan keterangan tersebut dapatlah diketahui bahwa ditinjau dari sudut bahasa kompilasi dapat diartikan sebagai usaha untuk mengumpulkan sumber-sumber (informasi, karangan dsb) dari berbagai literatur dan dijadikan satu untuk mempermudah pencarian. Hal ini dipertegas oleh Abdurrahman dalam bukunya Kompilasi Hukum Islam di Indonesia:

Kompilasi dari persepektif bahasa adalah kegiatan pengumpulan dari berbagai bahan tertulis yang diambil dari berbagai buku/tulisan mengenai sesuatu persoalan tertentu. Pengumpulan dari berbagai sumber yang dibuat oleh beberapa penulis yang berbeda untuk ditulis dalam suatu buku tertentu, sehingga dengan kegiatan ini semua bahan yang diperlukan dapat ditemukan dengan mudah. ${ }^{26}$

Penyusunan Kompilasi Hukum Islam (KHI) dapat dipandang sebagai suatu proses transformasi hukum Islam dalam bentuk tidak tertulis ke dalam peraturan perundangundangan dalam penyusunannya dapat dirinci pada dua tahapan. Pertama, tahapan pengumpulan bahan baku, yang digali dari berbagai sumber baik tertulis maupun tidak tertlis. Kedua, tahapan perumusan yang didasarkan kepada peraturan perundangundangan yang berlaku dan sumber hukum Islam (al-Qur'an dan Sunnah Rasul), khususnya ayat dan teks yang berhubungan dengan substansi Kompilasi Hukum Islam (KHI). ${ }^{27}$

Tahapan pengupulan bahan baku dalam penyusunan Kompilasi Hukum Islam (KHI) dilakukan melalui beberapa jalur. Jalur pertama, penelaahan kitab fiqh dari berbagai madzhab, mencakup 160 masalah hukum keluarga. Penelaahan kitab fiqh itu dilakukan oleh para pakar di tujuh IAIN. Jalur kedua, wawancara dengan 181 ulama yang tersebar di sepuluh daerah hukum Pengadilan Tinggi Agama waktu itu (Aceh, Medan, Padang, Palembang, Bandung, Surakarta, Surabaya, Banjarmasin, Ujung Pandang, dan Mataram). Jalur ketiga, penelaahan produk Pengadilan dalam lingkungan Peradilan Agama yang terhimpun dalam 16 buku. Buku tersebut terdiri atas empat jenis, yakni himpunan putusan PTA, Himpunan Fatwa Pengadilan, Himpunan Yurisprudensi Pengadilan Agama, dan Law Report Tahun 1977 sampai tahun 1984. Jalur keempat, kajian perbandingan hukum keluarga yang berlaku di Maroko, Mesir, dan Turki. Di samping itu, memperhatikan aspek-aspek historis dan kemajemukan masyarakat bangsa Indonesia, baik secara vertikal maupun secara horizontal.

Dalam perumusan Kompilasi Hukum Islam (KHI), secara substansial, dilakukan dengan mengacu kepada sumber hukum Islam, yakni al-Qur'an dan Sunnah Rasul, dan secara hierarki mengacu kepada peraturan perundang-undangan yang berlaku. Dengan demikian, Kompilasi Hukum Islam (KHI) merupakan suatu perwujudan hukum Islam yang khas di Indonesia yang bercorak keindonesiaan. Berkenaan dengan kedudukan Kompilasi Hukum Islam (KHI) dalam sistem hukum nasional, diukur oleh unsur-unsur sistem hukum nasional sebagaimana telah dikemukakan. $^{28}$

Gambaran tentang pengumpulan bahan baku dan perumusan KHI dapat diperagakan secara sederhana, sumber, lagalitas, dan adaptasi dalam pengumpulan bahan dan perumusan KHI. ${ }^{29}$
${ }^{25}$ Tim Penyusun Kamus, Kamus Besar Bahasa Indonesia. (Jakarta: Balai Pustaka, 2002), hal. 584 Indonesia........ hal. 11
${ }^{26}$ Abdurrahman, Kompilasi Hukum Islam di
27 Cik Hasan Bisri, Kompilasi Hukum Islam dalam Sistem Hukum Nasional, (Jakarta: Logos Wacana Ilmu, 1999), h.8.

${ }^{28}$ Ibid., h.9.

${ }^{29}$ Ibid., h. 10. 


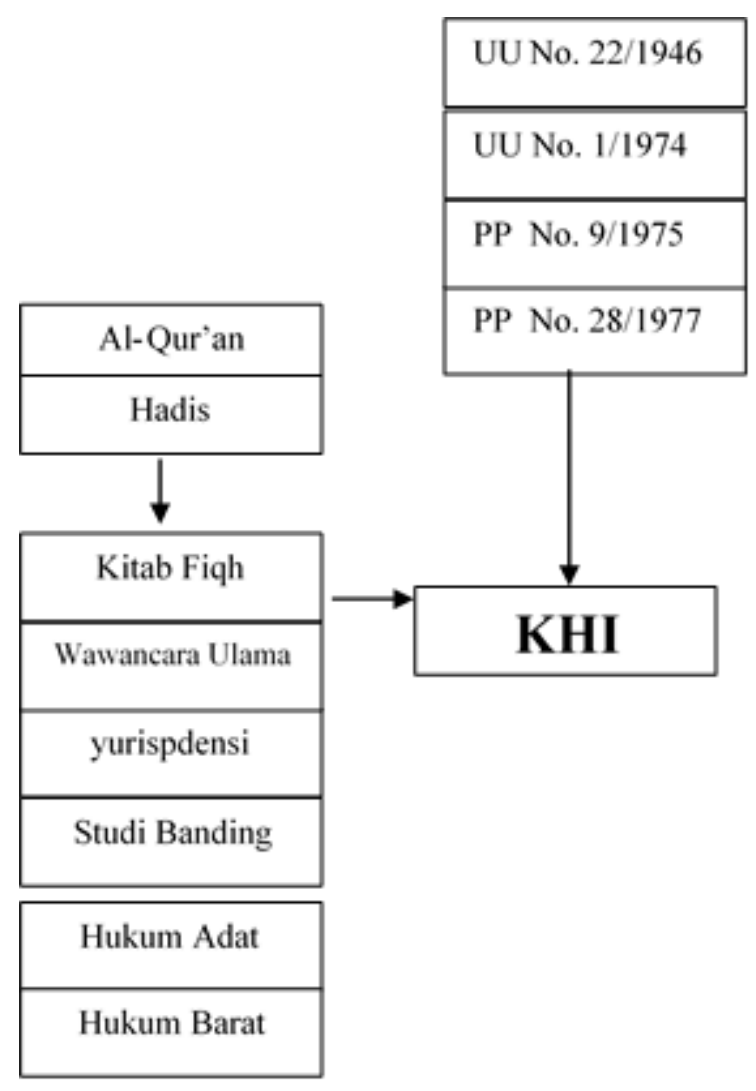

Keterangan:

1. Hukum Islam dari berbagai bentuk sebagai sumber utama.

2. Peraturan perundang-undangan sebagai sumber legalisasi.

3. Hukum barat dan hukum Adat yang diadaptasi dan dimodifikasi.

Kompilasi Hukum Islam (KHI) yang tertuang dalam Instruksi Presiden No. 1 Tahun 1991, dilaksanakan dengan Keputusan Menteri Agama No. 154 Tahun 1991. Perumusan Kompilasi Hukum Islam (KHI) mengenai perkawinan berdasarkan pada perundang-undangan No. 22 Tahun 1946 jo. Undang-undang No. 32 Tahun 1954 dan Undang-undang No. 1 Tahun 1974, sebagaimana dapat dilihat pada gambar di atas. Sedangkan yang berhubungan dengan bidang kewarisan tidak ditemukan peraturan perundang-undangan yang dijadikan rujukannya. Namun demikian, dapat ditemukan dalam yurisprudensi yang memuat bagian-bagian tertentu dari hukum kewarisan. Hal itu menunjukan bahwa Kompilasi Hukum Islam (KHI) merupakan hukum positif Islam untuk melaksanakan peraturan perundangundangan yang berlaku. Ia memiliki konsistensi dengan peraturan perundangundangan yang kedudukannya lebih tinggi dan dijadikan rujukan sebagaimana telah disebutkan. ${ }^{30}$

\section{Landasan, Tujuan dan Isi Kompilasi Hukum Islam (KHI)}

Perumusan Kompilasi Hukum Islam dipengaruhi oleh beberapa landasan:

a. Landasan historis: terkait dengan pelestarian hukum Islam, didalam kehidupan masyarakat bangsa, ia merupakan nilai-nilai yang abstrak dan sakral kemudien dirinci dan disistematisasi dengan penalaran logis. Kompilasi hukum Islam ini juga merupakan sistem untuk memberikan kemudahan penyelenggaraan peradilan agama di Indonesia. Dan didalam sejarah Islam pernah dua kali ditiga negara, hukum Islam diberlakukan sebagai perundang-undangan negara: (1). Di India masa Raja Aung Rang Zeb yang membuat dan yang memberlakukan perundang-undangan Islam yang terkenal dengan fatwa a lamfiri, (2). Di Kerajaan Turki Usmani yang terkenal dengan nama Majallah al-Ahkam al- Adliyah, (3). Hukum Islam pada tahun 1983 dikodifikasikan di Sudan. ${ }^{31}$ Pembatasan 13 kitab yang dilakukan oleh Departemen Agama pada tahun 1958 yang digunakan diperadilan agama adalah merupakan upaya kearah kesatuan dan kepastian hukum yang sejalan dengan apa yang dilakukan dinegara-negara tersebut. Dan dari situlah kemudian timbul gagasan untuk membuat kompilasi hukum Islam sebagai buku hukum dipengadilan agama.

\footnotetext{
${ }^{31}$ Direktorat Pembina Peradilan Agama,
} Kompilasi Hukum Islam di Indonesia, ( Jakarta : 2003), cet. ke-3, h.133 
b. Landasan yuridis : landasan yuridis tentang perlunya hakim memperhatikan kesadaran hukum masyarakat ialah UU No.14 tahun 1970 pasal 20 ayat 1 yang berbunyi : “ Hakim sebagai penegak hukum dan keadilan wajib menggali, mengikuti dan memahami nilai-nilai hukum yang hidup dalam masyarakat". Kemudian juga yang terkait dengan tuntutan normatif, pasal 49 UU No 7 tahun 1989 menyatakan bahwa Hukum Islam dibidang perkawinan, kewarisan dan perwakafan berlaku bagi orang-orang Islam $^{32}$, dalam UU perkawinan pasal 2 ayat 1 menyatakan bahwa perkawinan sah apabila dilakukan menurut hukum masing-masing agamanya. ${ }^{33}$

Hal ini menunjukkan bahwa hukum perkawinan bagi orang Islam adalah hukum Islam begitu juga bagi agama lain. Maka untuk tercapainya kepastian hukum maka dituntut adanya hukum tertulis yang memiliki daya ikat, oleh karena itu KHI merupakan jawabannya. Undang-undang No.14 tahun 1970 pasal 20 ayat 1 .

c. Landasan fungsional: Kompilasi disusun untuk memenuhi kebutuhan hukum di Indonesia, yang mengarah pada unifikasi mazhab dalam hukum Islam dan sistem hukum Indonesia kompilasi merupakan kodifikasi hukum yang mengarah pada pembangunan hukum nasional. Kompilasi hukum Islam sekarang diberlakukan dilingkungan peradilan agama di Indonesia, berfungsi sebagai petunjuk dalam memeriksa,mengadili dan memutuskan perkara-perkara yang berhubungan dengan keperdataan orang Islam, kompilasi tidak dihasilkan dari legislasi dewan perwakilan rakyat tetapi merupakan hasil diskusi para ulama yang digagaskan oleh Mahkamah Agung dan Departemen Agama yang melibatkan beberapa perguruan tinggi Islam di Indonesia. Dasar legalitas berlakunya KHI adalah Intruksi Presiden tahun 1991 tanggal 10 juni 1991.

${ }^{32}$ Undang-Undang PeradilanAgama, op.cit,

h.60

${ }^{33}$ Undang-Undang Nomor 1 Tahun 1974, (

Yogyakarta : Galang Prees, 2009 ), cet. ke-1,
Landasan dalam artian ini sebagai dasar hukum keberadaan Kompilasi Hukum Islam (KHI) di Indonesia adalah sesuai dengan Instruksi Presiden No. 1 Tahun 1991 tanggal 10 Juni 1991. Sudah jelas bahwa dalam bidang perkawinan, kewarisan, dan wakaf bagi pemeluk-pemeluk Islam telah ditetapkan oleh Undang-undang yang berlaku adalah hukum Islam, maka Kompilasi Hukum Islam (KHI) itu yang memuat hukum materiilnya dapat ditetapkan dengan Keputusan Presiden/Instruksi Presiden. Pendapat tersebut antara lain didasarkannya pada disertasi dari A. Hamid S. Attamimi. Dan selanjutnya ia mengatakan bahwa Instruksi Presiden tersebut dasar hukumnya adalah pasal empat ayat satu Undang-undang Dasar 1945, yaitu kekuasaan Presiden untuk memegang kekuasaan pemerintahan Negara. Apakah dinamakan Keputusan Presiden atau Instruksi Presiden, kedudukan hukum-hukumnya adalah sama. Karena itu pembicaraan mengenai kedudukan kompilasi tidak mungkin dilepaskan dari Instruksi Presiden dimaksud. ${ }^{34}$

Instruksi Presiden ini ditujukan kepada Menteri Agama. Ini adalah merupakan Instruksi dari Presiden Republik Indonesia kepada Menteri Agama untuk menyebarluaskan Kompilasi Hukum Islam (KHI) yang sudah disepakati tersebut. Diktum keputusan ini hanya menyatakan:

PERTAMA: Menyebarluaskan Kompilasi Hukum Islam (KHI), yang terdiri dari:

a. Buku I tentang Hukum Perkawinan;

b. Buku II tentang Hukum Kewarisan;

c. Buku III tentang Hukum Perwakafan.

Sebagaimana diterima baik oleh para alim ulama Indonesia dalam lokakarya di Jakarta pada tanggal 2-5 Februari 1988 untuk

h. 12

\footnotetext{
${ }^{34}$ Abdurrahman, op.cit., h.53.
} 


$\begin{array}{lrr}\text { digunakan oleh Instansi } \\ \text { Pemerintah dan } & \text { oleh } \\ \text { masyarakat } & \text { yang } \\ \text { memerlukannya. } & \end{array}$

KEDUA: Melaksanakan Instruksi ini dengan sebaik-baiknya dan dengan penuh rasa tanggung jawab. ${ }^{35}$

Buku I Kompilasi Hukum Islam (KHI) tentang hukum Perkawinan yang terdiri atas 19 bab, yang terinci dalam 170 pasal. Dalam berbagai hal merujuk kepada peraturan perundang-undangan yang berlaku. Di samping itu ia merujuk kepada pendapat fuqaha yang sangat dikenal di kalangan ulama dan masyarakat Islam Indonesia. Hal itu menunjukkan bahwa Kompilasi Hukum Islam (KHI) menjadi pelaksana bagi peraturan perundang-undangan, terutama yang berkenaan dengan keberlakuan hukum Islam (bagi orang Islam) di bidang perkawinan sebagaimana diatur dalam ketentuan pasal 2 ayat (1) Undang-undang No. 1 Tahun 1974.

Di bidang kewarisan dan perwakafan (Buku II danBuku III), pada dasarnya merupakan suatu peralihan bentuk dari hukum kewarisan dan hukum perwakafan menurut pandangan fuqaha (dalam lingkungan tradisi besar, meminjamkan istilah Redfield) ke dalam bentuk qanun. Namun demikian, terdapat ketentuan yang terkait dengan masyarakat majemuk, khususnya dengan tradisi yang berlaku dalam berbagai satuan masyarakat lokal, di antaranya ketentuan Pasal 185 tentang ahli waris pengganti atau "pengganti ahli waris" (plaatsvervulling), Pasal 189 tentang harta warisan berupa lahan pertanian yang kurang dari 2 hektar sebagai warisan"kolektif", dan pasal 209 tentang wasiat wajibah antara orang tua angkat dan anak angkat. ${ }^{36}$

\footnotetext{
${ }^{35} \mathrm{Ibid}, \mathrm{h} .54$.

${ }^{36}$ Cik Hasan Bisri, op.cit., h. 12.

${ }^{37}$ Ibid, h.11.

${ }^{38}$ Badruddin, Kajian Agama Islam, (Serang:
}

STIKes Faletehan, 2008), h.17.
Kompilasi Hukum Islam (KHI) berhubungan dengan kemajemukan tatanan hukum dalam hukum nasional. Ia berhubungan dengan peradilan, dalam hal ini pengadilan dalam lingkungan Peradilan Agama, yang mengalami perubahan penting berkenaan dengan berlakunya Undang-undang No. Tahun 1989. Ia juga berhubungan dengan kemajemukan hukum keluarga, antara lain hukum perkawinan yang mengenal diferensiasi menurut agama sebagaimana tercermin dalam Pasal 2 ayat (1) Undangundang No. 1 Tahun 1974 tentang Perkawinan. Secara singkat, Kompilasi Hukum Islam (KHI) disusun dan disebarluaskan untuk memenuhi kekosongan hukum substansial bagi orangorang yang beragama Islam, terutama berkenaan dengan penyelesaian sengketa keluarga di pengadilan dalam lingkungan Peradilan Agama. ${ }^{37}$

Kodifikasi hukum nasional dalam bidang-bidang tertentu ditetapkan dalam Garis-garis Besar Haluan Negara (GBHN) dan telah menjadi komitmen kita sebagai bangsa untuk melaksanakannya. Namun, kodifikasi hukum kewarisan dalam bentuk unifikasi yang berlaku bagi semua warga negara agaknya akan merupakan masalah. Ini disebabkan karena hukum kewarisan Islam adalah bagian dari agama Islam. Dari uraian yang telah dikemukakan di atas, jelas bahwa sumber garis-garis hukum kewarisan adalah sumber agama Islam yaitu al-Qur'an yang dijelaskan dengan Sunnah Rasulullah. Pedoman pokok dan sumber hukum dalam agama Islam. $^{38}$ Dalam kerangka dasar agama Islam digambarkan bahwa iman dan hukum merupakan bejana yang berhubungan, salinng isi mengisi. Keduanya tidak mungkin dapat dipisahkan. Oleh karena itu hukum kewarisan merupakan bagian dari agama Islam (kecuali beberapa hal yang dikembangkan oleh pemahaman manusia, yang disebut fiqh). ${ }^{39}$

${ }^{39}$ Muhammad Daud Ali, Hukum Islam, (Jakarta: Raja Grafindo Persada, 2011), cet.ke-16, h.333 
Landasan dan tujuan dari penyusunan Kompilasi Hukum Islam (KHI) itu dapat dilihat dari penjelasan umum dari kompilasi tersebut yang menyatakan sebagai berikut: ${ }^{40}$

a. Bagi bangsa dan negara Indonesia yang berdasarkan Pancasila dan Undang-undang Dasar 1945, adalah mutlak adanya suatu hukum nasional yang menjamin kelangsungan hidup beragama berdasarkan Ketuhanan Yang Maha Esa yang sekaligus merupakan perwujudan kesadaran hukum masyarakat dan bangsa Indonesia.

b. Berdasarkan Undang-undang No. 1970 tentang Ketentuan Pokok Kekuasaan Kehakiman jo. Undang-undang No. 14 Tahun 1985 Tentang Mahkamah Agung, Peradilan Agama mempunyai kedudukan yang sederajat dengan lingkungan peradilan lainnya sebagai peradilan negara.

c. Hukum materiil yang selama ini berlaku di lingkungan Peradilan Agama adalah hukum Islam yang pada garis besarnya meliputi bidang-bidang hukum perkawinan, hukum kewarisan dan hukum perwakafan. Berdasarkan Surat Edaran Biro Peradilan Agama tanggal 18 Pebruari Nomor $\mathrm{B} / 1 / 735$, hukum materiil yang dijadikan pedoman dalam bidangbidang hukum tersebut di atas adalah bersumber pada 13 buah kitab yang kesemuanya (kebanyakannya) madzhab Syafi'i.

d. Dengan berlakunya Undangundang Nomor 1 Tahun 1974 tentang Perkawinan dan Peraturan Pemerintah Nomor 28 Tahun 1977 tentang Perwakafan Tanah Milik. Maka kebutuhan masyarakat

40 Yusuf Somawinata, "Hukum Kewarisan dalam Kompilasi Hukum Islam di Indonesia," dalam semakin berkembang sehingga kitab-kitab tersebut dirasakan perlu pula untuk diperluas, baik dengan menambahkan kitab-kitab madzhab yang lain, memperluas terhadap ketentuan di dalamnya, fatwa para ulama, maupun perbandingan dengan hukum yang berlaku di negara yang lain.

e. Hukum materiil tersebut perlu dihimpun dan diletakkan dan suatu dokumentasi yustisia atau buku Kompilasi Hukum Islam (KHI), sehingga dapat dijadikan pedoman bagi para hakim di lingkungan badan Peradilan Agama sebagai hukum terapan dalam menyelesaikan perkara-perkara yang diajukan kepadanya.

Selain landasan yuridis, Kompilasi Hukum Islam (KHI) juga disusun berdasarkan landasan fungsional Kompilasi Hukum Islam (KHI) adalah fiqh Indonesia yang disusun dengan memperhatikan kondisi kebutuhan umat Islam Indonesia. Ia bukan merupakan madzhab baru, tetapi ia mengarah kepada menyatukan (unifikasi) berbagai pendapat madzhab dalam hukum Islam, dalam rangka upaya menyatukan persepsi para hakim dengan hukum Islam, menuju kepastian hukum bagi umat Islam. ${ }^{41}$

Sekalipun Kompilasi Hukum Islam (KHI) di Indonesia telah diberlakukan dan dijadikan pedoman oleh para hakim di lingkungan Peradilan Agama dalam menyelesaikan berbagai permasalahan hukum Islam bagi umat Islam, hal ini tidak berarti bahwa Kompilasi Hukum Islam (KHI) merupakan hasil final yang tidak membutuhkan penyempurnaan. Sebagaimana watak fiqh yang selalu mengalami perubahan karena berbagai pertimbangan kebutuhan (baik waktu atau tempat), maka Kompilasi Hukum Islam (KHI) pun salah satu sumber pembentukannya mengacu kepada fiqh,

Alqalam: Jurnal Keagamaan dan Kemasyarakatan, Vol. 26, No.1 (Januari-April, 2009), h.140.

${ }^{41}$ Suparman Usman, op.cit., h.147-148. 
dimungkinkan adanya perubahan, baik isi maupun produk hukum yang memayunginya.

Keberhasilan bangsa Indonesia melahirkan Kompilasi Hukum Islam (KHI), merupakan salah satu prestasi besar dalam upaya mewujudkan kesatuan hukum Islam dalam bentuk tertulis. Kebutuhan akan adanya Kompilasi Hukum Islam (KHI) sudah lama dirasakan dan upaya ke arah itu pada dasarnya sudah namak berbarengan dengan sejarah pertumbuhan badan Peradilan Agama di Indonesia. Upaya untuk memenuhi kebutuhan akan adanya Kompilasi Hukum Islam (KHI) sebagai acuan hukum materiil bagi Peradilan Agama, merupakan rangkaian pencapaian sebuah cita-cita bangsa Indonesia, yang menyatu dan tidak bisa dipisahkan dalam sejarah pertumbuhan Peradilan Agama, sejak lembaga peradilan ini didirikan. ${ }^{42}$

\section{DAFTAR PUSTAKA}

\section{Buku}

Al-Ashqia, M. Hafidz. 2011. Kaya Wajib Bagi Orang Islam. Yogyakarta: Khazanah Sulaiman,

Mardani. 2010. Hukum Islam, Yogyakarta: Pustaka Belajar.

Khaeruman, Badri. 2010. Hukum Islam. Bandung: Pustaka Setia

Harahap, Yahya. 1993. Kedudukan Kewenangan dan Acara Peradilan Agama. Jakarta: Pustaka Kartini

Ali, Zainuddin. 2006. Hukum Islam : Pengantar Ilmu Hukum Islam di Indonesia. Jakarta: Sinar Grafika

Usman, Suparman. 2011. Hukum Islam. Jakarta: Gaya Media Pratama

Syafe'i, Zakaria. 2012. Sanksi Hukum Riddah dan Implementasinya di Indonesia. Jakarta: Media Pustaka

Jalil, Basiq. 2006. Pengadilan Agama di Indonesia. Jakarta : Kencana Prenada Media Group
Hasan Bisri, Cik. 1999. Kompilasi Hukum Islam dalam Sistem Hukum Nasional. Jakarta: Logos Wacana Ilmu

Badruddin, 2008. Kajian Agama Islam. Serang: STIKes Faletehan, 2008

Daud Ali, Muhammad. 2011. Hukum Islam, Jakarta: Raja Grafindo Persada

\section{Jurnal dan Dokumen}

Yusuf Somawinata, "Al-Maslahah AlMursalah dan Implikasi Terhadap Dinamisasi Hukum Islam Di Indonesia," dalam Al-Ahkam: Jurnal Hukum, Sosial dan Keagamaan, Vol. 4, No. 2 (Juli-Desember, 2010)

Hani Solihah, "Sejarah Hukum Keluarga Islam di Indonesia," dalam Syakhsia: Jurnal Hukum Perdata Islam, Vol. 2, No. 2 (Agustus-Desember)

Dirjen Binbaga Islam, Sejarah Penyusunan Kompilasi hukum Islam di Indoesia, (Jakarta: Departemen Agama RI, 1991)

Abdurrahman, Kompilasi Hukum Islam di Indonesia.

Direktorat Pembinaan Badan Peradilan Agama, Inpres RI No.1 Tahun 1991 Kompilasi Hukum Islam di Indonesia, (Jakarta: Depag RI, 2000)

Abdul Halim, Politik Hukum Islam di Indonesia Kajian Posisi Hukum Islam Dalam Politik Hukum Pemerintahan Orde Baru dan Era Reformasi, ( Tt : Badan Litbang dan Diklat Departemen Agama RI, 2008 )

Sohari, "Gugatan Pengarusutamaan Gender (TPG) dan JIL Terhadap Kompilasi Hukum Islam(KHI)," dalam Syakhsia: Jurnal Hukum Perdata Islam, Vol. 3, No. 1 (Juli-Desember,2011)

Abdurrahman, Kompilasi Hukum Islam , (Jakarta: Akademika Pressindo, 2007)

Amir Syarifuddin, Hukum Perkawinan Islam di Indonesia antara Fiqh Munakahat dan Undang-undang Perkawinan, (Jakarta: Kencana, 2006)

42 Yusuf Somawinata, "Hukum Kewarisan op.cit., h.142. 
Abdurrahman, Kompilasi Hukum Islam di Indonesia

Tim Penyusun Kamus, Kamus Besar Bahasa Indonesia. (Jakarta: Balai Pustaka, 2002)

Abdurrahman, Kompilasi Hukum Islam di Indonesia........

Yusuf Somawinata, "Hukum Kewarisan dalam Kompilasi Hukum Islam di Indonesia," dalam Alqalam: Jurnal Keagamaan dan Kemasyarakatan, Vol. 26, No.1 (Januari-April, 2009)

Direktorat Pembina Peradilan Agama, Kompilasi Hukum Islam di Indonesia, ( Jakarta : 2003)

Undang-Undang Nomor 1 Tahun 1974, (Yogyakarta : Galang Prees, 2009)

\section{Internet}

aafandia.wordpress.com/2009/05/20/instruksi -presiden-ri-nomor-1-tahun-1991-tentangkompilasi-hukum-islam/ 